\title{
Municipal Grants for Sports and the Merits of a Voucher System in the Czech Republic
}

\author{
Marek Pavlik ${ }^{1}$ and Michiel S. de Vries ${ }^{2}$
}

\begin{abstract}
In Europe in 2008 governments spent 36 billion Euro on sports subsidies. One of the main goals for spending public money on sports is to increase the participation of people in sports. The Czech Republic even spent more than average on sports. However, the participation in sports in this country lags behind the European average. This article investigates whether the way such grants are given can explain this. One of the outcomes of this paper is that transparency in the decision-making process in sports-grants allocation is lacking, resulting in many cases of fraud. This paper also investigates the merits of an alternative way of allocating money, which is, using sports vouchers as a tool for allocating public resources. The experience with that instrument is, although rare, quite positive, especially in reducing fraud. Although there is a lot of hesitance against using vouchers, the experience shows that this is primarily based on prejudice and unfamiliarity with this instrument.
\end{abstract}

\section{Keywords}

Sports policy, grant, voucher system, transparency, subsidies

\section{Introduction}

A significant portion of public budgets in Europe are directed towards sports subsidies. This is partly the case because the EU believes that "in grassroots sport, equal opportunities and open access to sporting activities can only be guaranteed through

1 Assistant Professor, Department of Public Economics, Faculty of Economics and Administration, Masaryk University, Brno, Czech Republic.

2 Professor, Department of Management Sciences, Radboud University Nijmegen, The Netherlands. 
strong public involvement." (Commission of the European Union 2007, 13). The most recent available comparative figures show that in 2008, European national governments spent $€ 10.7$ billion on sports, i.e. $€ 21.5$ per person, per year. The funding of sports from government at the local level is estimated to be even 2.5 times as high (€26 bn).

There are of course huge differences within Europe, as the amounts of money spent on sports are strongly related to the wealth of a country. In the Czech Republic, the amount of money estimated to be spent by government on sports in 2008, just before the financial crisis, was $€ 168$ million. (Eurostrategies 2011, 57). This amounts to $31 \%$ of all revenues for the sports sector in the Czech Republic. Compared to the Western European countries, where the share of sports-sector revenues coming from government is on average below $20 \%$, and compared to other Central European countries, where the share of sports sector revenues coming from government is on average above $40 \%$, the financial role of government in sports in the Czech Republic is in the middle.

One of the main goals of spending public money on sports is to increase participation. Previous research among individuals and sports organizations showed that participation in sports serves important goals such as increased health and social cohesion. (Eurostrategies 2011, 43). However, as the same study on grassroots sports-funding in the EU showed, sports participation in the EU is still rather low: "The number of individuals who practice sports as a member of a club is estimated at 76 million across the EU-27. This represents $16 \%$ of the population." (Eurostrategies 2011,36). There are huge differences in terms of participation among countries, but there are also differences among genders and income classes, and participation seems to decrease with age. In the Czech Republic, participation in sports is far below the European average. Less than $30 \%$ of the Czech population participates in sports regularly and less than $10 \%$ are sports club members. (Eurostrategies 2011). The figures reflecting the average amounts of public spending on sports with resulting participation rates that are much lower than expected raise the following questions: What is wrong with public spending on sports in the Czech Republic, and and are there alternative ways to persuade more people to become active in sports. It could be that the target group is not reached because due to fraudulent behavior (part of) the subsidies are wasted. This article investigates the degree to which that is indeed the case. The main goal is to assess the transparency of the allocation of public grants for sports organizations on the municipal level in the case of the Czech Republic and discuss one possible method of how to improve the transparency - a vouchers system. This could provide an answer to the question of why public support for sports in the Czech Republic is above average, while the participation in amateur sports is far below average. In order to address this problem five sub-questions will be answered: 
1. What is known from previous research on sports grants and especially on the merits of vouchers?

2. What is the structure of providing grants to sports clubs in the Czech Republic?

3. To which degree are the criteria for providing grants in the Czech Republic transparent?

4. To which degree are these subsidies susceptible to fraud?

5. What does the experience of municipalities in which a voucher system is in use say about the merits of vouchers compared to classic ways of providing subsidies?

In order to answer these questions, we first give a brief overview of what is known about the effectiveness of public expenditures on sports (section 2). Next, the existing structure of public funding of sports in the Czech Republic is described (section 3 ). We then focus on problems in the funding policies of local governments towards the sports sector (section 4). In the last part of this paper, we present the outcomes of our investigation into an alternative method of giving grants to the sports sector, namely through a voucher system (section 5 ).

Two separately performed analyses are presented. The first analysis addresses data related to the actual practices of selected municipalities in funding sports organizations and examines the availability and quality of information about the process for providing grants to sports NGOs. The second analysis presents the results of a large-scale survey among sports clubs.

\section{Previous research on the effectiveness of public involvement in sports}

Despite the enormous amount of public money invested in sports, surprisingly little is known about the effectiveness of providing grants to the sports sector in comparison with other parts of the public sector. Consequently, different opinions about its effectiveness are possible, including:

1) Grants are useful and benefit society. They persuade people to behave in a desired way by diminishing the costs of the desired behavior, i.e. joining a sports organization. An EU study showed that one quarter of all people do not participate in sports because of the costs involved (Eurostrategies 2011, 39). For the clubs and the national sports federations, the cost for the participant is perceived to be the main barrier, followed by issues related to the quality and availability of infrastructures (ibid., 40). This claim is supported by the positive statistical relationship between government expenditures on sports and participation rates in EU countries. However, this might be an illusory association explained by 
general wealth, that is GDP per capita. Sports participation and public funding of sports are both positively related to a nation's wealth.

2) Grants may not have any real effect. It might be kind of a fiscal illusion. Grants could be seen as the result of political decisions, without being related to any economic or non-economic benefit for society. People are persuaded to become active in sports for reasons besides the cost. As a study on sports participation showed, lack of time is mentioned twice as often as the high cost as a barrier to participation in sports (Eurostrategies 2011,39). Empirical research on the effectiveness of grants to the sports sector is not always positive. Martin (2001) and Jones (2002) provided arguments against the support of sports activities/organizations from public budgets in general, because little (or no) positive economic impacts were achieved by such funding, and the process of grant allocation seems to be more a political than a rational economic process (Kantor 1995).

3) Grants could be effective, but will only benefit society under specific circumstances. It is not whether or how many grants are provided, but the way in which they are provided that has an effect. Previous research indicated two problems in the present method of allocating funds: their allocation is far from transparent and therefore does not support increased participation, and they are not directed to the target group, i.e. the potential participants, but to the sports associations. Some authors claim that in order to be effective, transparency in the decision-making process of allocating money is the first necessity (Stirton and Lodge 2001). Only then can a decent assessment of the effects of sports grants be made. A transparent environment in grants allocation is not a sufficient condition for achieving positive effects for society, but it is seen as a necessary condition. If transparency is lacking in the field of sports-grants allocation, it is possible to seriously doubt the positive effects of grants on society. Wolman and Spitzley (1999) recommend that public funding of sports focus attention on participants as a target group instead of on the grant amounts. One way to do this is by changing public spending from supporting sports associations to supporting potential participants.

Both goals - increased transparency and the target-oriented provision of grants could be accomplished by introducing a voucher system as an alternative to giving the funds directly to the sports associations and clubs. "Voucher systems of distribution are defined as regimes in which individuals receive (pay for or are allocated) entitlements to a good or service which they may 'cash in' at some specified set of suppliers, which then redeem them for cash or the equivalent from a funding body. Vouchers are used in the distribution of private goods and services as well as in public services." (Cave 2001, 59).

The application of vouchers for public-resource allocation was originally introduced for the education system. One of the earliest suggestions for the govern- 
ment use of vouchers, made by Milton Friedman in 1962, was as a way to fund education, without excessive government intervention in the market (Friedman and Friedman 1982). Vouchers typically transfer purchasing power to the client. An example of the use of vouchers is in the healthcare sector. Health vouchers are used as a tool for increasing the possibility for patients to choose among providers and for targeting subsidies to the poor and/or high-risk/vulnerable groups (see more in Gorter et al. 2003), and as an alternative means of funding healthcare services (Wilson 1999; Peacock and Segal 2000).

Table 1

Merits of using vouchers in providing sports grants

\begin{tabular}{|c|c|c|}
\hline & Advantages (benefits) & Disadvantages (costs) \\
\hline Recipients & $\begin{array}{l}\text { - Motivation to continue or start with } \\
\text { sports } \\
\text { - Freedom of consumer choice } \\
\text { - Indirect involvement in public affairs }\end{array}$ & $\begin{array}{l}\text { - Time (and cost) for collecting } \\
\text { the voucher from the local } \\
\text { municipality }\end{array}$ \\
\hline $\begin{array}{l}\text { Sports } \\
\text { clubs/ } \\
\text { organiza- } \\
\text { tion }\end{array}$ & $\begin{array}{l}\text { - Increasing interest in services } \\
\text { granted by the voucher } \\
\text { - Guaranteed support not dependent } \\
\text { on political decision-making process }\end{array}$ & $\begin{array}{l}\text { - Administrative stress } \\
\text { - Economic cost of administration } \\
\text { - The risk that no public resources } \\
\text { would be gained if no vouchers } \\
\text { from members were gathered } \\
\text { - Vouchers are set to a fixed } \\
\text { amount of money, hence cost } \\
\text { differences among sports are not } \\
\text { taken into consideration } \\
\text { - The value of the voucher can } \\
\text { be floating (derived from the } \\
\text { number of collected vouchers). } \\
\text { Hence, the sum of money can be } \\
\text { unpredictable }\end{array}$ \\
\hline $\begin{array}{l}\text { State/ } \\
\text { local mu- } \\
\text { nicipality }\end{array}$ & $\begin{array}{l}\text { - Establish a transparent system } \\
\text { based on inhabitants' revealed } \\
\text { preferences instead of on a political } \\
\text { decision } \\
\text { - Absence of the necessity to } \\
\text { formulate a clear sports-grant } \\
\text { policy - consumer choice determines } \\
\text { allocation }\end{array}$ & $\begin{array}{l}\text { Direct economic cost: } \\
\text { - Costs of voucher distribution } \\
\text { - Increased administrative stress, } \\
\text { especially if vouchers are used } \\
\text { in combination with the previous } \\
\text { system } \\
\text { Other impacts } \\
\text { - Vouchers cannot be used in } \\
\text { investment decisions }\end{array}$ \\
\hline
\end{tabular}

Source: Pavlík 2013

Using sports vouchers as tool for allocating public resources is still quite rare, though early attempts with sports vouchers were made in the USA, and there are examples of sports vouchers in the Czech Republic. One problem with vouchers was mentioned by Crompton (1983). He indicated that "there is a danger that resources may be allocated to the most persuasive rather than the most responsive organizations." Valkama and Bailey (2001) categorize sports vouchers as service vouchers within the public sector. They see vouchers as a useful tool for employers to moti- 
vate/reward employees. Their taxation of vouchers enables the possibility of using vouchers as an allocation tool similar to school vouchers. Although Cave (2001, 84) did not mention sports vouchers we can use his taxation of sports grants. The principal objective is the redistribution of funds taking into account information problems. Cave pleads for privatized funding (i.e. private suppliers can reimburse the vouchers) with a reasonable amount of competition between sports clubs over members.

Based on the literature, the following merits of voucher systems can be distinguished (see Table 1)

One of the questions addressed below concerns the opinions in the Czech Republic on the need for and merits of the introduction of a voucher system.

\section{Methods}

The following sections present the results of our research on public support of sports clubs in the Czech Republic. This research was conducted in order to answer the question of why public support for sports in the Czech Republic is average, but the participation in amateur sports is far below average.

The research used different types of analysis. One type of analysis was desk research, investigating what is known about the subject and the situation in the Czech Republic. Subsequently a comparative case study was conducted in order to investigate the procedures in 15 municipalities in the Czech Republic. This was done through content analysis of policy documents and sending out a questionnaire to key figures. We sought information about how municipalities deal with requests for funding, which criteria were used in decision-making, and whether these criteria were publicly displayed. We sought data to answer two questions: (1) "Is there a document specifying the general principles for granting subsidies?" and (2) "Is a document containing the specific criteria for obtaining subsidies readily available?" The results are presented in the next section, giving an overview of sports funding in the Czech Republic. In the other type of analysis, the first author conducted a survey of sports clubs in the Czech Republic in spring 2011. A list of 19 questions was sent to 1567 sports clubs; 430 completed forms were returned. Of those 430 responses, 406 were from not-for-profit organizations. It is difficult to estimate the total number of sports organizations in the Czech Republic, hence we cannot evaluate if the responses are sufficient for a representative sample. The questionnaire was sent to approximately $60 \%$ of the sports organizations enrolled in the Czech Sport Association (ČSTV). ČSTV includes 72 sports federations, and it is estimated that $70 \%$ of athletes are members of the ČSTV. Among the questions in the survey, the following six are analyzed in the next section: (1) "Did you receive support ${ }^{3}$ from

3 "Support" means financial grants and/or non-financial support. 
your municipality?"; (2) "Did you receive support from your sports federation/association?"; (3) "How should grants be allocated?"; (4) "How are grants allocated in reality?"; (5) "Have you noticed a problem with corruption in relation to sportsgrants allocation?"; and (6) "What is your opinion of using vouchers for the allocation of grants?" It was expected that the results would vary according to the size of the municipalities. Therefore, it was necessary to distinguish among small and large municipalities. An overview of the municipality sizes is provided in Table 2. The table shows that the distribution of small, medium, and large municipalities as well as the distribution of sports clubs among them is fairly even. There is a slight overrepresentation of medium-sized municipalities and sports clubs.

Table 2

The number of selected municipalities

\begin{tabular}{|l|c|c|}
\hline $\begin{array}{c}\text { Number of inhabitants } \\
\text { in the municipality }\end{array}$ & $\begin{array}{c}\text { Percentage of sports clubs } \\
\text { in each category }\end{array}$ & $\begin{array}{c}\text { Percentage of selected } \\
\text { municipalities in each } \\
\text { category }\end{array}$ \\
\hline less than 5,000 & 12 & 13.3 \\
\hline $5,000-10,000$ & 11 & 13.3 \\
\hline $10,000-50,000$ & 32 & 26.7 \\
\hline $50,000-150,000$ & 19 & 20.0 \\
\hline $150,000-300,000$ & 7 & 6.7 \\
\hline over 300,000 & 19 & 20.0 \\
\hline & & 100.0 \\
\hline Total: & 100 & 15 \\
\hline Number of respondents: & 430 & \\
\hline
\end{tabular}

Source: author

Finally, we conducted phone interviews with several Czech municipalities that have implemented a voucher system. The interviews were conducted in February 2013 with the officer responsible for the voucher system.

\section{Public financing of sports organizations in the Czech Republic}

This section describes the financial relationship between government and the sports sector in the Czech Republic. This research is based on an investigation of the policies in 15 municipalities, and a survey of sports organizations.

In most countries, including the Czech Republic, there are four sources of revenue for the sports sector: the national government, sub-national government, lotteries and participants. In 2007 , about $€ 45$ million was transferred to amateur sports 
from lotteries (Eurostrategies,2011 Vol. II, 53). Central government added another $€ 93$ million, $60 \%$ of which was allocated to amateur sports. Local government spent 71 million, $63 \%$ of which was allocated to amateur sports. The participants themselves contributed the largest share, i.e. $€ 300$ million (ibid., 56).

The public money from the national government goes mainly to general sports associations and sports-branch federations. At the local level, government especially supports the sports clubs (see Table 3 ).

\section{Table 3}

Review of sports NGOs and their public-sector partners

\begin{tabular}{|c|c|c|c|}
\hline $\begin{array}{c}\text { Type of } \\
\text { sports NGO }\end{array}$ & Description & Subsidizer & $\begin{array}{c}\text { Decision } \\
\text { maker }\end{array}$ \\
\hline $\begin{array}{l}\text { General Sport } \\
\text { Associations } \\
\text { (GSA) }\end{array}$ & $\begin{array}{l}\text { There are nine GSAs, which } \\
\text { encompass all sports-branch } \\
\text { federations/unions in the Czech } \\
\text { Republic. These nine were } \\
\text { stakeholders of the biggest lottery } \\
\text { company in the Czech Republic. } \\
\text { Their role consists of providing } \\
\text { financial and non-financial support } \\
\text { for sports federations/unions. It } \\
\text { seems that their role has been } \\
\text { decreasing since } 2011 \text {. }\end{array}$ & $\begin{array}{l}\text { Ministry of Education, } \\
\text { Youth and Sport } \\
\text { Ministry of Defense } \\
\text { Ministry of the Interior } \\
\text { EU funds/projects }\end{array}$ & $\begin{array}{l}\text { Ministry } \\
\text { committee }\end{array}$ \\
\hline $\begin{array}{l}\text { Sports branch } \\
\text { federations/ } \\
\text { unions/ } \\
\text { associations }\end{array}$ & $\begin{array}{l}\text { Members of one of the GSAs. } \\
\text { Each sports federation/union } \\
\text { incorporates sports clubs } \\
\text { in the given sports branch. } \\
\text { These federations/unions can } \\
\text { be divided into regional sub- } \\
\text { federations/unions. }\end{array}$ & $\begin{array}{l}\text { Regional municipalities } \\
\text { Ministry of Education, } \\
\text { Youth and Sport } \\
\text { EU funds/projects }\end{array}$ & $\begin{array}{l}\text { Represent- } \\
\text { ative body }\end{array}$ \\
\hline Sports clubs & $\begin{array}{l}\text { Basic unit. Most sports clubs } \\
\text { are NGOs; however, some of } \\
\text { them operate as Itds, joint stock } \\
\text { companies or sole proprietors. }\end{array}$ & $\begin{array}{l}\text { Regional and local } \\
\text { municipalities } \\
\text { EU funds/projects } \\
\text { Sports branch } \\
\text { federation }\end{array}$ & $\begin{array}{l}\text { Represent- } \\
\text { ative body }\end{array}$ \\
\hline
\end{tabular}

Source: Pavlík 2013

The Czech system of public financial support involves three governmental levels. The national budget is focused on the support of national sports teams and amateur sports. The national grants are allocated to sports federations/associations or directly to primary/secondary schools providing extensive sports education. The most important role is played by the Ministry of Education, Youth and Sport, which allocates approximately $90 \%$ of the financial resources. The Ministry of Defense is focused on military sports and also provides sports centers for selected sports branches (most of the Czech Summer Olympic medalists are enrolled in the army). The Ministry of the Interior provides support for police and fire-fighter sports. 
The Ministry of Education, Youth and Sport annually presents "Principles of state support of sports". Within these "principles" the "financial programs" are established. Currently there are four programs (national sports teams; talented-youth sports; high schools with special sports classes; and general sports activities). The principles of each program address the methodology of resource allocation.

The second level of public financial support consists of the fourteen regions of the Czech Republic. The resources are quite often allocated according to a published methodology. The allocation rules are provided by the municipality body, and there are noticeable differences among regions in the key principles they use. The grant system is based on the condition of a request by a prospective recipient. Hence, there is no automatic allocation. In addition, strategic documents concerning sports policy are not always available.

Local municipalities are the third level of the public financial support system. Most of their financial grants are dedicated to non-profit local sports organizations or local sports events. There are huge differences among municipalities in the system of grants provision and transparency (Pavlík 2012).

The following graph describes the grants provided by governmental and nongovernmental institutions and their relationships. The arrows show the cash flow among the institutions. There is a difference between general sports associations and sports federations/associations/unions s. $^{4}$

A general review of financial cash flow is presented in Table 4. The majority of total resources come from the municipal budget (regionals and local municipalities together). The grants allocated to national sports teams amounted to CZK $714,617,000$ ( $€ 28.5$ billion) in 2011 , which is approximately a third of the total state expenditures on sports. However, there are also resources dedicated to investment or construction and technical reconstruction of sports facilities. These facilities are used by both national sports teams and other sports clubs. The total portion of resources dedicated to national sports teams cannot be precisely counted due to facility-sharing and the reallocation of financial resources through sports federations/associations.

4 There are nine GSAs, which encompass all sports-branches federations/unions in the Czech Republic. These nine were stakeholders of the biggest lottery company in the Czech Republic. Their role consists of providing financial and non-financial support for sports federations/unions. It seems that their role has been decreasing since 2011. Sports federations (or associations or unions) are the organizations that represent given sport branches (i.e. ice-hockey clubs are members of the Czech Ice-hockey Association, which is a member of the Czech Sport Association (the largest of the general sports associations)). 


\section{Graph 1}

The institutional system of sports support in the Czech Republic

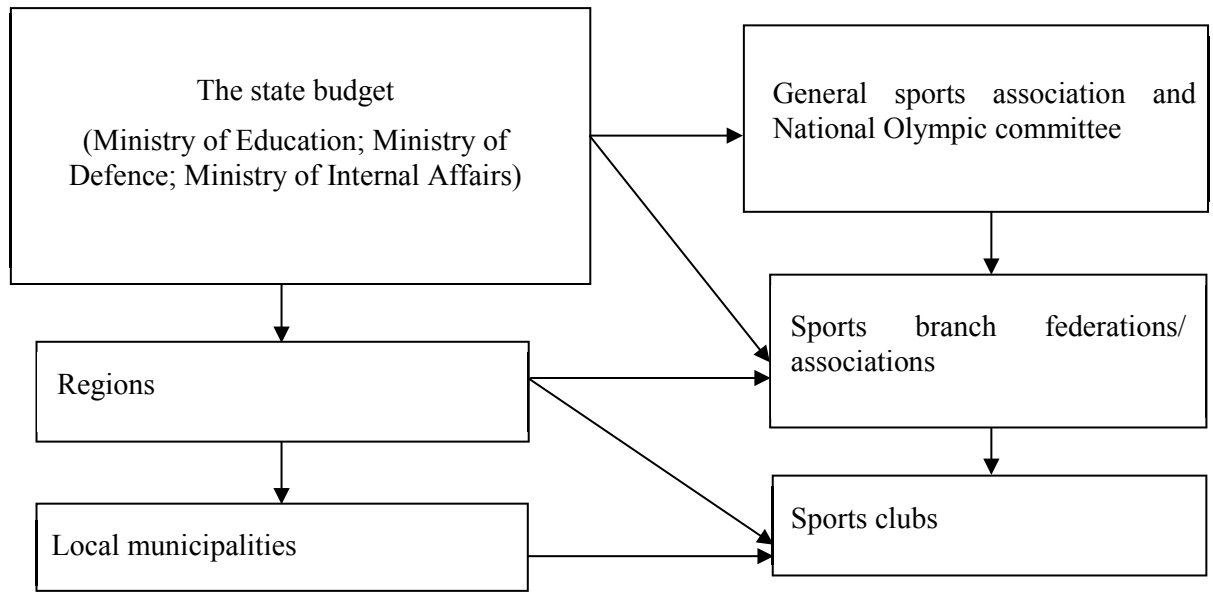

Source: Nemec, Nemec and Pavlík (2013)

\section{Table 4}

Expenditure of the state budget and local government budgets on culture and sports in 2011 (EUR million)

\begin{tabular}{|l|c|c|c|c|c|c|c|}
\hline $\begin{array}{c}\text { Expenditure } \\
\text { on culture } \\
\text { and sports }\end{array}$ & \multicolumn{3}{|c|}{ State budget } & \multicolumn{3}{c|}{ Local government budgets } \\
\hline & $\begin{array}{c}\text { Current } \\
\text { expendi- } \\
\text { ture }\end{array}$ & $\begin{array}{c}\text { Capital } \\
\text { expendi- } \\
\text { ture }\end{array}$ & subtotal & $\begin{array}{c}\text { Current } \\
\text { expendi- } \\
\text { ture }\end{array}$ & $\begin{array}{c}\text { Capital } \\
\text { expendi- } \\
\text { ture }\end{array}$ & subtotal & $\begin{array}{c}\text { Expend- } \\
\text { iture, } \\
\text { total }\end{array}$ \\
\hline $\begin{array}{l}\text { Physical } \\
\text { training }\end{array}$ & 72.28 & 33.48 & 105.76 & 182.52 & 144.32 & 326.84 & 432.6 \\
\hline $\begin{array}{l}\text { Leisure } \\
\text { activities \& } \\
\text { recreation }\end{array}$ & 10 & 0.88 & 10.88 & 88.64 & 51.76 & 140.4 & 151.28 \\
\hline $\begin{array}{l}\text { Other } \\
\text { activities } \\
\text { related to } \\
\text { culture and } \\
\text { sports }\end{array}$ & 108.52 & 1.92 & 110.44 & 182.28 & 55.28 & 237.56 & 348 \\
\hline
\end{tabular}

Source: Ministry of Education, Youth and Sports of the CR, adapted by the authors from the Czech statistical office.

Note: expenditures in Czech koruna (CZK) were converted to Euros at the exchange rate of CZK 25 per Euro. 


\section{Opinions about sports grants in the Czech Republic at the local level}

The outcome of the survey of 430 sports clubs in the Czech Republic by the first author shows that sports clubs receive grants and the non-financial support of municipalities more frequently than they receive support from their own sports federation/association. In Figure 1, the results of two survey questions are provided: 1) Do you receive financial or non-financial support from your municipality? 2) Do you receive financial or non-financial support from your sports federation/association? Respondents were allowed to choose one of four answers displayed in the chart.

About $80 \%$ of the sports clubs received financial and/or non-financial support from their local government, while less than $50 \%$ got support from their sports federation. Hence, sports clubs are heavily dependent on local government support. This conforms previous research results in the Slovak Republic, where Nemec et al. (2009) showed a risk for sports clubs to be highly dependent on public budgets.

Although it is pretty clear how the Czech national government allocates its funds, namely through the Czech sports association ČSTV, much less is known about the support of sports organizations by local government. Formally, the decision-making process involves three steps: (1) A hearing with the sports (or education) committee, which is an adviser for the municipal body. The committee usually concludes the hearing with some recommendations for the council and the representative body of the municipality. This hearing is not open to the public. (2) The proposal submitted by the committee is discussed by the council of the municipality and it is concluded with recommendations for the representative body. This process is also closed to the public. (3) The representative body makes a decision, usually in accordance with the recommendations of the council and the committee. The results of the decision-making process are then made public.

The comparative case study does not illuminate the criteria used by local governments, and indicates a lack of transparency in the decision-making processes. Table 5 shows that most municipalities lack explicit principles underlying their funding and that explicit criteria are incomplete or absent in most municipalities. This indicates a mostly non-transparent funding system for sports organizations.

No significant differences were found among municipalities in the three given size categories. One might expect the problem of non-transparency to be seen more often in small municipalities, but this was not the case. Most municipalities stated that they use certain criteria. However, these criteria are not specified by the decision makers. For instance, sports clubs with more youth members - a possible target group for sports-club funding - do not know if they are in a better situation for funding than sports clubs with more medal winners. Such criteria, sufficiently 
specified for transparent decision-making, are available in only one-third of the municipalities.

\section{Figure 1}

Comparison of support received from local municipalities and sports federations (in percentage of respondents, 2011)

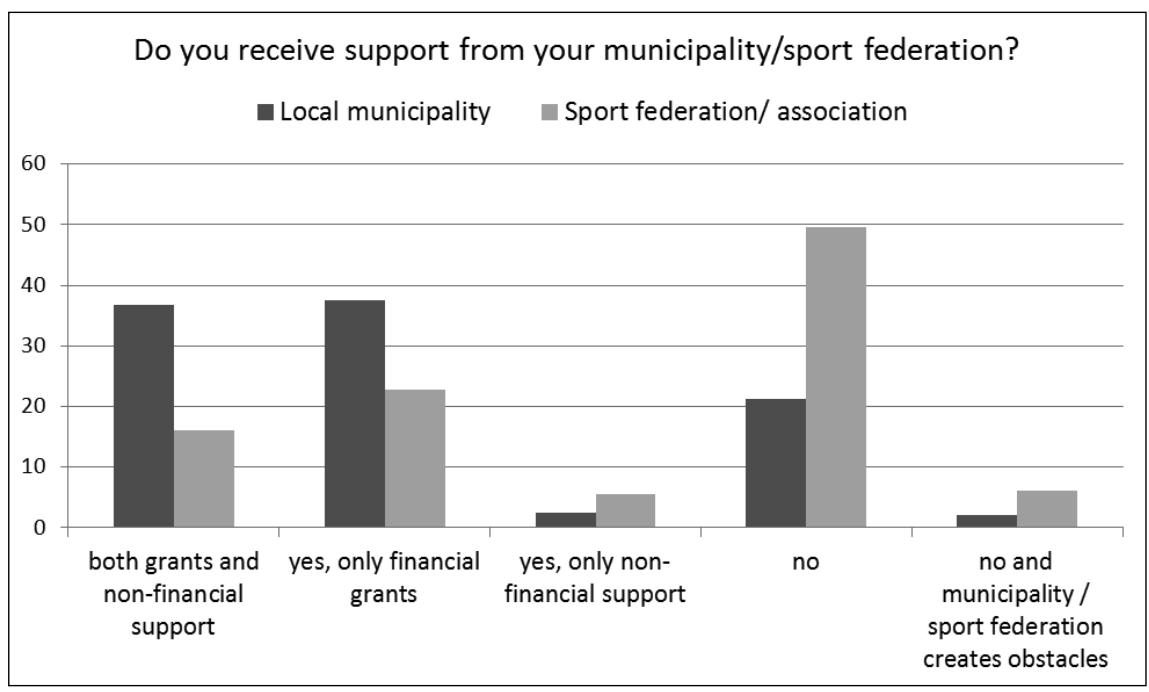

Source: author

Table 5

Results of municipality analysis

\begin{tabular}{|l|c|c|c|}
\hline \multicolumn{1}{|c|}{ Results in percentage } & yes & partly yes & no \\
\hline Availability of principles of the sports granting policy & 13.33 & 26.67 & 60.00 \\
\hline $\begin{array}{l}\text { Publicly displayed document containing clear criteria of } \\
\text { the examination process of grant requests }\end{array}$ & 33.33 & 46.67 & 20.00 \\
\hline
\end{tabular}

Source: author. Based on an initial analysis of 15 selected municipalities.

More important than the lack of scholarly knowledge is the fact that sports organizations themselves are also often unsure how municipalities arrive at the decision of whether to allocate subsidies.

Based on the questionnaire results, we can conclude that $76 \%$ of sports clubs apply for grants on a regular basis. The respondents expect that these applications follow a transparent process, i.e. that clear criteria crucial for grants allocations are available. When asked how funds should be allocated, sports organizations men- 
tioned membership rates, specific target groups such as young people, and the popularity of the sport (See Figure 2).

\section{Figure 2}

How should grants be allocated?

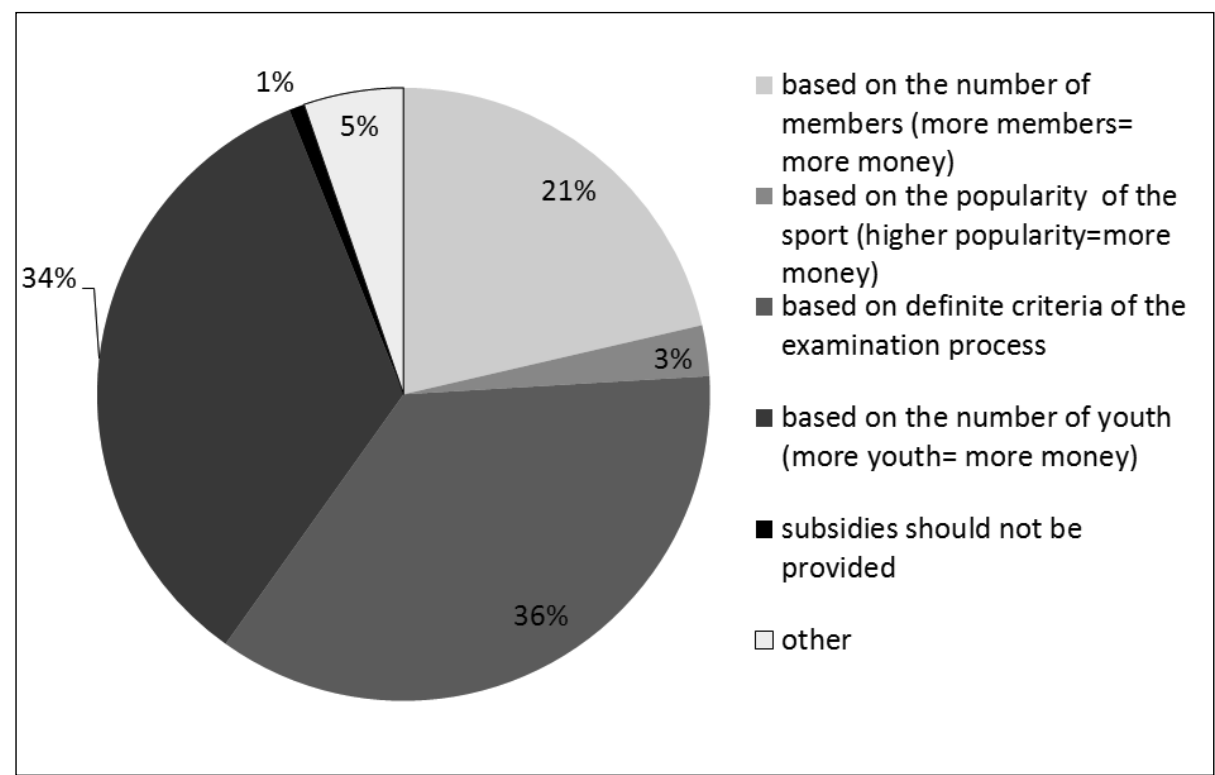

Source: Pavlík (2013)

However, when asking how such decisions are made in reality, only $22 \%$ could identify clear criteria, and another $22 \%$ identified membership rates as important. More than $50 \%$ stated that the decision is made in some other way, $44 \%$ of which stated that local government decisions in this regard are especially based on informal relationships between the representatives of the sports organizations and the decision makers (see Table 6).

Table 6

How are grants allocated in reality?

\begin{tabular}{|l|c|}
\hline \multicolumn{1}{|c|}{ based on definite criteria of the examination process } & $\mathbf{2 1 . 7 1}$ \\
\hline based on the number of members (more members=more money) & 22.23 \\
\hline based on informal relationship with decision-makers & 43.37 \\
\hline based on the popularity of the sport (higher popularity=more money) & 3.31 \\
\hline other & 9.38 \\
\hline
\end{tabular}

Source: author 
Based on these figures we can conclude that in the Czech Republic having friendly relations with the local subsidizer seems more important for receiving money than any formal criteria. Sports organizations have to provide a lot of information about their organization and about the purpose of the request, but in most cases they have no information about the examination criteria and preferred allocation alternatives.

Does this imply something like corruption in relation to the local grants to sports organizations? Not necessarily, but the lack of transparency is seen as a cause of corruption.

A significant number of respondents from the sports clubs in the survey have observed corruption, although its occurrence is less noted than the lack of transparency. Experience with direct forms of corruption was reported by $13.3 \%$ of the sports clubs. In combination with the reported occurrence of symbolic corruption, this means that $30.7 \%$ of the respondents reported that the decision-making process involved corruption (see Figure 3). We also noticed that those respondents who supported the idea of a voucher system were facing the corruption more frequently in comparison with the total results (see part 3).

Figure 3

Have you noticed any corruption in relation to sports grants?

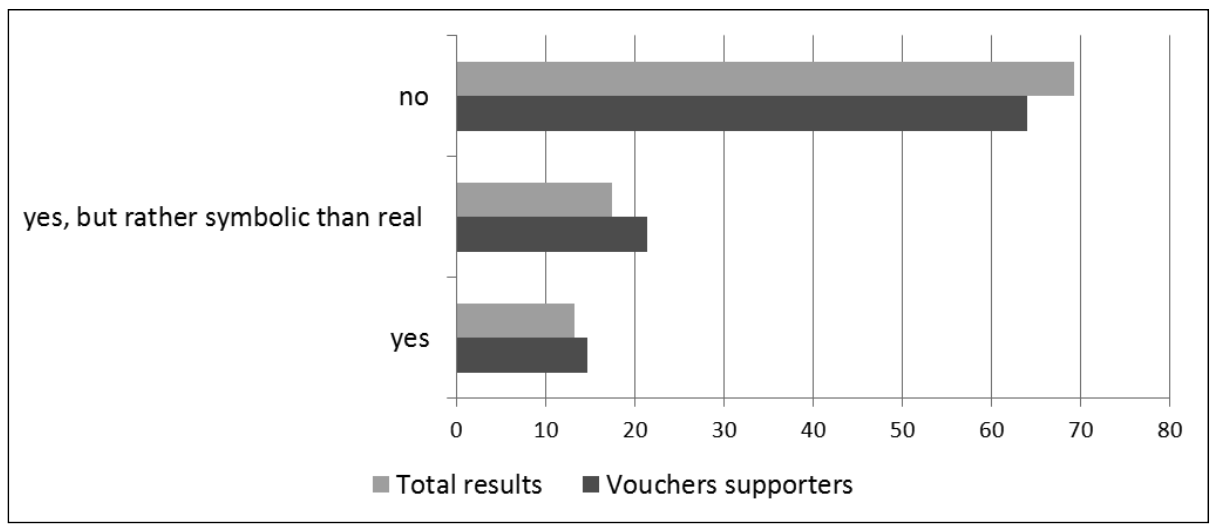

Source: author

A preliminary conclusion based on these findings is that decisions about subsidies, funds and grants from local authorities to sports organizations in the Czech Republic deviate from the norms and standards that would be expected. Such decisions seem to lack clear principles or criteria, and to lack transparency in the pro-

5 Symbolic corruption is a situation when, before or after deciding, a decision-maker (politician) or bureaucrat (responsible for formal aspects of granting) receives a non-financial gift with low monetary value (e.g. a bottle of alcohol or a box of chocolates). 
cess. One unpleasant result was that some form of corruption was mentioned by $30 \%$ of all sports clubs.

\section{Using public funds for providing vouchers}

Could a different method of public funding make a difference? We investigate the actual use of the voucher system and the opinions of sports organizations about such a system. In theory, this use of public funds is very simple because the target group is directly approached and sports participation is directly influenced. Furthermore, the chance of corruption is decreased, because it is unlikely that the recipients of the vouchers will try to bribe the provider. Finally, such a system increases the freedom of the recipient in terms of the choice of where to spend the voucher.

Although the majority of public funds are spent through sports clubs and associations, the idea of vouchers used for grants allocation is not unknown in the Czech Republic. We provide examples of three cities where a part of the total financial resources dedicated to sports was allocated according to a vouchers program.

The vouchers system was implemented in three cities in the Czech Republic: Hodonín with 25,000 inhabitants and the longest history with a voucher system (since 2008), Opava with 58,000 inhabitants, and Poděbrady with almost 14,000 inhabitants). Yet another city (Prostějov with 44,000 inhabitants) is considering a voucher system (Bursa 2012). Each city has its own system, but there are similarities. The voucher system in all these cities is based on shared principles. First, a person who has the right to receive a voucher has to visit the municipal office to get it. Next, the voucher (one or all parts) is given to the sports club preferred by the voucher bearer. Third, the sports clubs submit the received vouchers to the municipality, and consequently they receive financial support. The value of the voucher can be established explicitly before distribution (€40 per voucher in 2012 in Prostějov) or derived from the total amount dedicated to subsidies and the number of vouchers presented by the sports club (Hodonín - ex-post $€ 85$ per voucher in 2012). Based on the available information, the value of vouchers allocated to one recipient is between $€ 40$ and 100 per year. Although voucher systems are usually more transparent than typical grant systems, we noticed difficulties in obtaining information about vouchers on the web pages in these cities.

All of the cities use vouchers as a supplementary method of allocating financial support for selected groups of recipients. However, differences can be found in the systems.

The first variable in the voucher system is the definition of the target recipient group by age. Hodonín (2012a, 2012b, 2012c, 2012d) and Opava enabled vouchers only for 6-18 or 6-19 year olds; Poděbrady does not apply age restrictions. A direct grant from the municipal budget excludes a sports club from the voucher system in 
Opava (2012a, 2012b). It is possible to get a voucher even if the recipient does not have a permanent address in the city in Hodonín.

Another variable is the divisibility of the voucher into parts (Hodonín and Opava enable division into two parts, Poděbrady (2012) into three parts). The divisibility of the voucher means that each part of the voucher can be given to different organizations or all parts can be given to only one.

Table 7

Main differences among the voucher system in analyzed municipalities

\begin{tabular}{|l|c|c|c|c|c|}
\hline \multicolumn{1}{|c|}{ City } & $\begin{array}{c}\text { Determination } \\
\text { of the value of } \\
\text { voucher }\end{array}$ & $\begin{array}{c}\text { Expenditure on } \\
\text { one recipient in } \\
\text { CZK (2012) }\end{array}$ & Target group & $\begin{array}{c}\text { Number } \\
\text { of parts }\end{array}$ & $\begin{array}{c}\text { Number of } \\
\text { supported } \\
\text { recipients } \\
\text { (2012) }\end{array}$ \\
\hline Hodonín & $\begin{array}{c}\text { Floating } \\
\text { (ex post) }\end{array}$ & 2118 & Age 6-18 & 2 & $875(2009)$ \\
\hline Opava & $\begin{array}{c}\text { Floating } \\
\text { (ex post) }\end{array}$ & 1000 & Age 6-19 & 2 & 966 \\
\hline Poděbrady & $\begin{array}{c}\text { Floating } \\
\text { (ex post) }\end{array}$ & $\begin{array}{c}\text { youth 900; } \\
\text { seniors 300 }\end{array}$ & No age limit & 3 & NA \\
\hline $\begin{array}{l}\text { Prostějov } \\
\text { (proposal) }\end{array}$ & $\begin{array}{c}\text { Fixed } \\
\text { (ex ante) }\end{array}$ & - & Age 6-19 & 2 & - \\
\hline
\end{tabular}

Source: Pavlík 2013 - updated by authors

Is there support for the more widespread use of the voucher system? Sports organizations were asked this question. The answers are given in Figure 4 . The dominant opinion is negative. The use of vouchers is feared for its bureaucratic consequences for both the sports organization and the municipality. The organization does not receive money directly; instead, vouchers represent a system in which the sports organization, in order to receive money, has to collect and return the vouchers, thus necessitating an administration system. Furthermore, the respondents fear that less popular sports will suffer under the voucher system. Nonetheless, a significant part of the respondents judge voucher systems positively because of the increased transparency.

There is no significant difference in answer of voucher supporters and total results in the case of the extension of support received from the municipality and the sports federation. However, we can notice some differences in the answers to the question of how grants are allocated in the reality. Those who support the idea of vouchers are more often convinced that grants are allocated according to informal relationships with decision-makers. 


\section{Figure 4}

Using vouchers for grants allocation

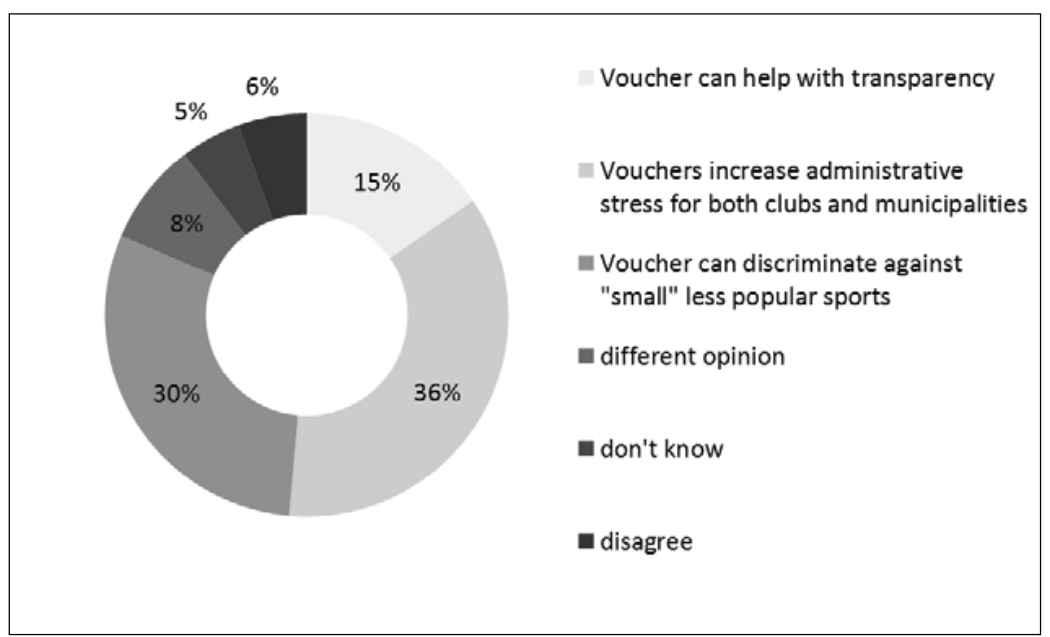

Source: author

Figure 5

How are grants allocated in reality?

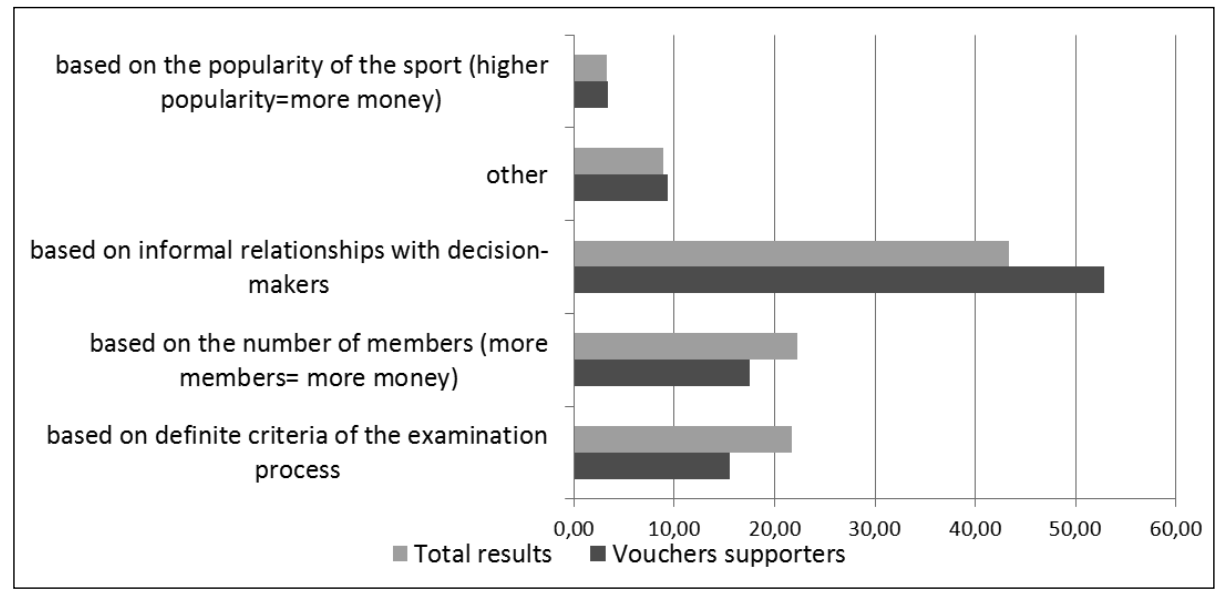

Source: authors

Note: This question allowed more than one answer, hence a correlation analysis with the answer about vouchers (also more than one answer allowed) is not possible. 
Both figures show that that there is much reluctance regarding the introduction of vouchers, especially because they are expected to increase administrative stress for both clubs and municipalities.

This hesitance is, however, based on prejudice. We interviewed the officials responsible in those municipalities that use vouchers. They reported that they were rather satisfied with this system. The most important benefits mentioned were that vouchers are considered to be indeed more transparent and fair; that they motivate parents to make their children join a sports club, as these parents were involved in the allocation process; and that administrative burdens were not increased. Most of the municipalities also reported that during the introduction of the system they noticed a somewhat negative reaction, but over time both individuals and sports clubs accepted the voucher system. Therefore, the experiences are rather positive. Voucher systems do increase the transparency of the provision of sports grants and, under the influence of parents, increase sports participation, especially of children. One has to be cautious with interpreting these remarks. The municipalities were unable to ground these opinions with hard data, and further research in the matter is therefore necessary.

\section{Conclusion}

This paper investigated sports-sector subsidies in the Czech Republic. From comparative figures on such subsidies and participation rates it could be concluded that the Czech Republic has a problem. Public money is sufficiently provided, comparable to other European countries. However, the sports participation rate is relatively low compared to other countries. Therefore this paper investigated whether something could be amiss in the procedures regarding the provision of funds to the sports sector in the Czech Republic, especially at the local level, and whether the introduction of an alternative - a voucher system - could resolve the issues involved.

The research showed that there is indeed a problem in Czech municipalities in relation to subsidizing sports organizations. We conducted a comparative case study and a large-scale survey among sports organizations. The outcomes were unpromising. Actual decisions about subsidies, funds, and grants from local authorities to sports organizations deviate from the norms and standards that would be expected. The decision-making processes lack clear principles. Criteria on which decisions to give money to a sports club should be based are often unavailable or non-existent. According to the sports clubs themselves, a friendly relationship with the provider of subsidies is the most important factor determining the amount of money their sports club gets. The unpleasant consequence of this is that some form of corruption in these decision-making processes is experienced by $30 \%$ of all sports clubs.

If this figure is a correct reflection of reality, this could explain the puzzle presented in the introduction of this article. Perhaps the Czech Republic spends an 
amount of money on sports which is above average, compared to other European countries. However, subtracting from the total amount of money spent, the percentage in which fraud seems to be involved, could explain why participation in sports is below average in the Czech Republic. Part of the money just does not reach the target group.

One of the challenges is to suggest an administratively simple, but transparent and efficient system for the decision-making concerning grants. In theory, a voucher system could help make the allocation of public funds to the sports sector more transparent and less corrupt. This system is already in use in three municipalities in the Czech Republic. Many a sports club acknowledges the advantage of voucher systems in terms of transparency, but they also fear the administrative burdens involved and fear that less popular sports will suffer from the introduction of a voucher system.

The examples of municipalities in the Czech Republic in which vouchers are used are positive. They reported that the voucher system could be a useful tool for supporting non-profit sports clubs at least as an additional method to the standard grant system based on the request of sports clubs and the decision-making process of the municipality (according to sometimes unclear criteria). This is further support for the conclusion that the introduction of a voucher system could resolve at least part of the problems visible in the Czech municipalities. Of course we acknowledge that experience with using vouchers is still scarce, but the outcomes of this investigation point to the possibility that vouchers can be a useful policy tool.

It does not imply that questions like "How can we adequately support sports through public budgets?" or "How can we increase the transparency of such support?" could be completely resolved by such a system, but if we ever want to improve sports support and achieve positive effects for society from public involvement, then we have to stop non-transparent grant allocation and consistently seek best practices.

\section{References}

Cave, M. 2001. "Voucher Programmes and their Role in Distributing Public Services." OECD Journal on Budgeting 1(1), 50-79. Available at www.oecd.org/ gov/budgeting/43515545.pdf (last accessed $1^{\text {st }}$ June 2013).

Commission of the European Union (2007). White Paper on Sport. Available at http://ec.europa.eu/sport/white-paper/doc/wp_on_sport_en.pdf (last accessed 15 June 2012).

Crompton, J.L. 1983. "Recreation Vouchers: A Case Study in Administrative Innovation and Citizen Participation." Public Administration Review 43(6), 537-546. 
Czech Statistical Office. 2012. "Expenditure of the State Budget and Local Government Budgets on Culture and Sports in 2011." Available at www.czso.cz/ csu/2012edicniplan.nsf/t/9D003B6FFD/\$File/0001122629.xls (last accessed $1^{\text {st }}$ June 2013).

Eurostrategies. 2011. Study on the Funding of Grassroots Sports in the EU: With a Focus on the Internal Market Aspects concerning Legislative Frameworks and Systems of Financing. Final report Volume II - Country Reports. Available at http://ec.europa.eu/sport/library/documents/f-studies/study-funding-grassroots-sports-finalreport-vol2.pdf (last accessed 18 December 2012).

Friedman, M. and R. Friedman. 1982. Capitalism and Freedom. Chicago: University of Chicago Press.

Gorter A., P. Sandiford, Z. Rojas and M. Salvetto. 2003. "Competitive Voucher Schemes for Health Background Paper." Instituto CentroAmericano de la Salud ICAS. Available at http://www.doh.state.fl.us/Family/dental/OralHealthcareWorkforce/Call20080407/Competitive_Voucher.doc (last accessed 20 September 2012).

Jones, C. 2002. "Public Cost for Private Gain? Recent and Proposed 'National' Stadium Developments in the UK, and Commonalities with North America." Area 34, 160-170.

Kantor, P. 1995. The Dependent City Revisited: The Political Economy of Urban Development and Social Policy. Boulder, CO: Westview.

Martin, F. 2001. "Should Cities Subsidize Nonprofit International Organizations? A Case Study and Cost Benefit Analysis." Journal of Urban Affairs 23, 361-373.

Nemec, J., J. Medved and V. Šagát. 2009. "Public Finance and Sports in Slovakia, Selected Problems and their Developments under the Economic and Financial Crisis." In Kubátová, K. (ed.)Proceedings of Teoretické a praktické aspekty VF. VŠE Praha, 2009, ISBN 978-80-245-1513-7.

Nemec, J., M. Nemec and M. Pavlík. 2013. "Public Financing of Sports in the Czech Republic and Slovakia." Zhang Wei; Zhang Tianbiao. Lecture notes in Management Science; volume 12; 2013 Fourth International Conference on Education and Sports Education. Hong Kong: Singapore Management and Sports Science Institute, 2013. s. 31-36, 6 s. ISBN 978-981-07-3900-3.

Pavlík, M. 2013. "Transparency in the Allocation of Municipal Grants for Sports and Voucher Systems in the Czech Republic." In Slaný, A. (ed.). Národohospodářský obzor. Brno: ESF MU Brno, in print.

Pavlík, M. 2012. "Transparency of Allocation of Public Grants for Czech Sport Organizations." In Špalková, D., Furová, L.(eds.). Proceedings of the $16^{\text {th }}$ International Conference - Modern and Current Trends in the Public Sector Research. Brno: Masarykova univerzita, Ekonomicko-správní fakulta, 252-260. 
Peacock S. and L. Segal. 2000. "Capitation Funding in Australia: Imperatives and Impediments." Health Care Management Science 3(2), 77-88.

Stirton, L. and M. Lodge. 2001. "Transparency Mechanisms: Building Publicness into Public Services." Journal of Law and Society 28, 471-489.

Transparency International. 2009. Global Corruption Barometer. Available at http:// www.transparency.cz/doc/global_corruption_barometer_2009_web.pdf (last accessed 20 September 2012).

Valkama, P. and S.J. Bailey. 2001. "Vouchers as an Alternative Public Sector Funding System." Public Policy and Administration 16, 32-58.

Wilson, J. 1999. "Acknowledging the Expertise of Patients and their Organizations." BMJ 319, 771-774.

Wolman, H. and D. Spitzley. 1999. “The Politics of Local Economic Development." In J. Blair and L. Reese (eds). Approaches to Economic Development: Readings from Economic Development Quarterly. Thousand Oaks, CA: Sage, 225-263.

\section{Information gathered about vouchers practice (last accessed 21 September 2012)}

Bursa, P. 2012. Materiál o možné metodě financování základních sportovních aktivit dětí a mládeže ve věkové kategorii 6.-19. Let (Prostějov). Available at http://www.pavelbursa.cz/sport.pdf.

Hodonín. 2012a. Zásady přidělování dotací na činnost organizací provozujících veřejněprospěšnou činnost. Available at www.hodonin.eu/VismoOnline_ActionScripts/File.ashx?id_org=4041\&id_dokumenty=1054449.

Hodonín. 2012b. Hodonínské listy 06/2012. Available at www.hodonin.eu/VismoOnline_ActionScripts/File.ashx?id_org=4041\&id_dokumenty=1058759

Hodonín. 2012c. Deník.cz: Hodonín rozdělil sportovní mládež 2,5mil. Kč. Available at http://hodoninsky.denik.cz/zpravy_region/hodonin-rozdelil-sportovni-mladezi-dva-a-pul-milionu-20120531.html.

Hodonín. 2012d. Zavedení systému přidělování dotací sportovním oddílům formou grantových poukázek. Available at

http: //www.google.cz/url ? sa =t \&rct=j\&q=transparentnost $\% 20$ rozd $\% \mathrm{C} 4 \% 9 \mathrm{Blov} \% \mathrm{C} 3 \% \mathrm{~A} 1 \mathrm{n} \% \mathrm{C} 3 \% \mathrm{AD} \% 20$ dotac\%C3\%AD \&source $=$ we $\mathrm{b} \& \mathrm{~cd}=3 \& \mathrm{cad}=\mathrm{rja} \& v e d=0 \mathrm{CCsQFj} A C \& u r l=h t t p \% 3 \mathrm{~A} \% 2 \mathrm{~F} \% 2 \mathrm{Fwww} \cdot \mathrm{mvcr}$. cz\%2Fsoubor\%2Fmanak-hodonin-grantove-poukazky-rezim-kompatibility-pdf.aspx\&ei=I4dZUNSfDabY4QSEyYDIAw\&usg=AFQjCNEUA8c2E3Sz FAUPiVdvUEXyk3mmsg.

Opava. 2012a. Granty statutární město Opava. Available at http://www.cstvopava. cz/oscstv-informace-pro-vas-granty-opava. 
Opava. 2012b. Granty 2012 - vyhodnocení poukázkového systému. Available at http://www.google.cz/url?sa=t\&rct=j\&q=opava\%20grantov\%C3\%BD\%20 pouk\%C3\%A1zkov\%C3\%BD\%20syst\%C3\%A9m\&source=web\&cd=4\&ved $=0 \mathrm{CFgQFjAD} \& u r l=$ http\%3A\%2F\%2Fwww.op4u.cz\%2Fpub\%2Fzmo\%2FZ 120423_010\%2Fz_010_021\%2Fz_010_021_000.doc\&ei=jHfKT_iGNMSUO pO56e8P\&usg=AFQjCNF5hJFyGK3zBhhSjmmvKwaCVx8zFA.

Poděbrady. 2012. Zásady městka Poděbrady pro poskytování dotací v oblasti volnočasových aktivit. Available at www.mesto-podebrady.cz/VismoOnline_ ActionScripts/File.ashx?id_org=12349\&id_dokumenty=5880.

Websites visited for the purpose of the transparency analysis. (last accessed 28 November 2011)

Brno: http://www.brno.cz/

Bystřice nad Pernštejnem: http://www.bystricenp.cz/

Chrast: http://www.mestochrast.cz/

Liberec: http://www.liberec.cz/

Opava: http://www.opava-city.cz/

Ostrava: http://www.ostrava.cz/

Pardubice: http://www.pardubice.eu/

Písek: http://www.mesto-pisek.cz/

Plzeň: http://www.plzen.eu/

Polnička: http://www.polnicka.cz/

Praha: http://www.praha.eu

Prostějov: http://www.mestopv.cz/

Šumperk: http://www.sumperk.cz

Třinec: http://www.trinecko.cz/

Vimperk: http://www.mesto.vimperk.cz/ 